Fernando, Adil Mubarak I Dampak Pembangunan Pedestrian di Pantai Air Manis Kota Padang dalam Rangka Kunjungan Wisatawan Ke Objek Wisata Pantai Batu Malin Kundang

Jurnal Manajemen dan llmu Administrasi Dublik (JMAN)

\title{
DAMPAK PEMBANGUNAN PEDESTRIAN DI PANTAI AIR MANIS KOTA PADANG DALAM RANGKA KUNJUNGAN WISATAWAN KE OBJEK WISATA PANTAI BATU MALIN KUNDANG
}

\author{
Fernando $^{1(a)}$, Adil Mubarak ${ }^{2(b)}$ \\ ${ }^{1}$ Jurusan Ilmu Administrasi Negara, Universitas Negeri Padang \\ ${ }^{2}$ Jurusan Ilmu Administrasi Negara, Universitas Negeri Padang \\ a)fernando38349@gmail.com, ${ }^{\text {b) }}$ adilmubarak@fis.unp.ac.id
}

\begin{abstract}
This study describes the impact of the development of pedestrians on the beach of Air Manis, Padang City on the increase in the number of visits to the Batu Malin Kundang beach tourism object. The author uses a theoretical concept based on Mill's opinion in the basis of tourism theory about the impact of developing tourist attractions. Descriptive analysis is the research method used and purposive sampling technique is used in determining research informants. By collecting data using interview, observation, and documentation techniques. The results of this study explain that with the development of a pedestrian on the air manis beach, the city of padang, increased tourist visits at Batu Malin Kundang beach tourism object because this pedestrian creates a new attraction for the air manis beach tourism area so it can also improve the economy of the people of Air Manis village. Even so, this development also produces environmental impacts such as poor cleanliness and the creation of water pollution near the Malin Kundang stone monument.
\end{abstract}

Keywords : Impact, Development, Pedestrians, Air Manis Beach

Corresponding author. Email.fernando38349@gmail.com

How to cite this article. Fernando \& Mubarak, A. (2021). Dampak Pembangunan Pedestrian di Pantai Air Manis Kota Padang dalam Rangka Kunjungan Wisatawan Ke Objek Wisata Pantai Batu Malin Kundang. Jurnal Manajemen dan Ilmu Administrasi Publik (JMIAP) Jurusan Ilmu Administrasi Negara Fakultas Ilmu Sosial Universitas Negeri Padang, Volume 3 (2), Hal. 117-125.

http://jmiap.ppj.unp.ac.id

Copyright $\odot 2021$. Published by Labor Jurusan Ilmu Administrasi Negara FIS UNP, Padang 
Fernando, Adil Mubarak। Dampak Pembangunan Pedestrian di Pantai Air Manis Kota Padang dalam Rangka Kunjungan Wisatawan Ke Objek Wisata Pantai Batu Malin Kundang

\section{PENDAHULUAN}

Sektor Pariwisata diyakini oleh banyak golongan sebagai sumber penggerak perekonomian, menciptakan lapangan kerja baru, mengurangi kemiskinan, media dalam meciptakan keharmonisan sosial menjadi prioritas utama pembangunan di berbagai negara. Dalam rangka mewujudkan keyakinan tersebut pariwisata harus dibangun dan dikembangkan secara terencana dan berkelanjutan, Kegiatan pariwisata merupakan suatu aktivitas bertamasya yang dilaksanakan dalam jangka waktu tertentu yang dilakanakan dari suatu daerah ke daerah lainnya dalam rangka meninggalkan daerahnya semula menggunakan suatu perencanaan yang matang dan dengan tujuan bukan untuk berusaha atau mencari pendapatan ditempat yang dikunjungi, tapi sematamata guna untuk menikmati aktivitas bertamasya dan rekreasi atau untuk memenuhi tujuan keinginan yang bermacam-macam. (Bahar, 2000).

Kegiatan pariwisata dapat membuka wawasan dan cakrawala berfikir terhadap orang-orang yang menikmatinya. Dengan pariwisata orang-orang dapat menikmati sesuatu yang baik, baru dan belum pernah didapat dari lingkungannya. Perjalanan wisata dilaksanakan dengan maksud mendapatkan kenikmatan, kepuasan, mengetahui sesuatu, memperbaiki kesehatan dan olahraga.

Pantai Air Manis merupakan salah satu kawasan objek wisata yang cukup terkenal yang terdapat di Sumatera Barat bukan tanpa sebab ini dikarenakan Pantai Air Manis menyimpan daya tarik pemandangan pantai yang indah, Tetapi tidak hanya keindahan pantai saja yang disuguhkan melainkan ada primadona utama yang menjadi daya tarik pengunjung untuk datang kesini yaitu adanya menumen Batu Malin Kundang yang sudah dikenal luas oleh masyarakat sumatera barat bahkan tidak hanya itu, diluar sumatera barat pun sudah banyak mengetahui akan batu malin kundang ini, bagaimana tidak
Batu Malin Kundang ini menyimpan cerita yang sudah melegenda yaitu kisah seorang anak yang durhaka pada orang tuanya lalu dikutuk menjadi batu.

Objek wisata Pantai batu malin kundang ini merupakan salah satu objek wisata alam di Sumatera Barat, lebih tepatnya berada di kelurahan air manis kecamatan padang selatan dan berada di bawah naungan Dinas Pariwisata dan kebudayaan (DISPARBUD) Kota Padang. Lokasi pantai terletak di pemukiman padat penduduk sehingga mudah bagi pengunjung menjangkau lokasi pantai ini. Apalagi setelah adanya pembangunan jalan baru yang melalui gunung padang dengan begitu dapat mempermudah akses menuju lokasi Pantai Air Manis tersebut. Kawasan wisata Pantai Air Manis ini lumayan banyak dikunjungi pengunjung saat akhir pekan ataupun hari libur dan bukan hanya pengunjung dari indonesia saja melainkan juga banyak pengunjung mancanegara yang datang untuk melihat dan menikmati keindahan pantai bahkan tidak sedikit yang mencicipi berselancar di pantai air manis ini.

Kunjungan wisata di objek wisata pantai air manis beberapa tahun belakangan ini mengalami naik turun atau dapat dikatakan tidak stabil bahkan ditahun 2019 mengalami penurunan kunjungan wisata yang tentunya membuat PAD dari sektor wisata pun menurun. Ini disebabkan oleh adanya kenaikan harga tiket dengan penyesuaian peraturan pemerintah terbaru.

Tabel 1. Jumlah Kunjungan Wisatawan Objek Wisata Pantai Air Manis 5 Tahun Terakhir

\begin{tabular}{ccc}
\hline No & Tahun & $\begin{array}{c}\text { Jumlah } \\
\text { Kunjungan/Orang }\end{array}$ \\
\hline 1. & 2015 & 14.067 \\
2. & 2016 & 48.400 \\
3. & 2017 & 66.137 \\
4. & 2018 & 417.143 \\
5. & 2019 & 232.943 \\
\hline
\end{tabular}

Sumber : DisParbud Kota Padang 2019 
Dalam rangka meningkatkan kualitas kawasan wisata pantai air manis maka pemerintah kota padang dalam hal ini yaitu dinas pariwisata dan kebudayaan kota padang bekerja sama dengan Kementrian Pekerjaan Umum dan Perumahan Rakyat (Kemen PUPR) melakukan kegiatan revitalisasi kawasan objek wisata pantai batu malin kundang, dan salah satunya dengan melakukan pembangunan jalur pedestrian yang dibangun dari pulau pisang ketek hingga ke batu malin kundang dan batu malin kundang yang tertimbun pasir pun juga akan diperbaiki, pembangunan pedestrian ini bertujuan untuk meningkatkan kualitas kawasan tersebut dan memberikan kenyamanan untuk para pejalan kaki di wisata pantai air manis serta diharapkan dapat meningkatkan daya tarik wisatawan.

Oleh karena itu ada beberapa indikator yang menentukan suatu daerah baik atau tidak dikembangkan sebagai tempat pariwisata yaitu adanya kegiatan bebas beraktivitas maksudnya yaitu melaksanakan perjalanan, menyuguhkan sarana transportasi dan komunikasi, adanya sarana akomodasi dan katering, adanya daya tarik daerah tujuan wisata (DTW), adanya anggaran untuk yang melaksanakan perjalanan itu, dan menjamin keamanan di kawasan tujuan wisata, adanya faktor-faktor kemudahan yang lebih besar dalam mendatangi kawasan tujuan wisata dan terjadinya komponen-komponen yang memadai dalam hal layanan termasuk bahan-bahan dan sarana informasi (Bakaruddin, 1990).

Pembangunan pedestrian pantai air manis ini di kerjakan oleh pemerintah kota padang dengan gagasan pantai air manis bersolek, tidak hanya menyuguhkan konsep pedestrian yang nyaman tetapi juga dilengkapi dengan taman yang akan menambah indah pemandangan wisata pantai air manis serta tidak terlupa pemerintah juga membenahi batu malin kundang yang sekarang ini telah tertimbun pasir menjadi terlihat lebih bagus. Oleh karena itu dengan adanya pembangunan pedestrian di kawasan wisata pantai air manis ini dapat meningkatkan kualitas kawasan tersebut dan meningkatkan kunjungan wisatawan tentunya.

Pembangunan dalam bidang pariwisata di Indonesia sudah dimulai sejak Repelita I tahun 1969, hal ini dilakukan melalui pembinaan sadar wisata bagi bangsa Indonesia yang juga dikaitkan dengan pembangunan nasional. Tap MPR No. II/1993 juga menegaskan bahwa pembangunan nasional berkaitan dengan sektor lainnya, yang berarti keberhasilan pariwisata turut mendukung keberhasilan pembangunan nasional.

Tetapi untuk mewujudkannya dirasa tidaklah mudah diperlukan sinergitas setiap komponen yang berkaitan dengan kawasan wisata pantai air manis ini terutama dalam pengelolaannya. Karena Dalam pengembangan objek wisata pantai air manis ini tidak terlepas dari berbagai kendala yang akan ditemukan seperti masih adanya bangunan liar yang ada di bibir pantai dan membuat terganggunya wisatawan dalam menikmati keindahan pantai air manis. lalu dengan adanya proses pembangunan daerah pedestrian ini membuat aktivitas pedagang sedikit terganggu karena daerah tempat berdagangnya akan dilakukan pembangunan serta pedagang harus dipindahkan untuk sementara waktu ke daearah yang tidak jauh dari pembangunan pedestrian tersebut.

Oleh karena itu layaknya suatu kawasan wisata maka, perlu ada manajemen pembangunan yang terintegrasi sehingga terpenuhi prasyarat wisata, paling tidak ada 3 hal yang direkomendasikan dalam mewujudkan nagari wisata berbasis lingkungan agar konsep yang sudah ada ini dapat berkembang secara baik yaitu bagaimana mewujudkan destinasi wisata yang dapat menjawab tiga pertanyaan utama yaitu sebagai tempat wisata apakah yang akan dilihat, apakah yang akan dikunjungi dan apakah yang dibeli. Selain itu, perlu membangun infrastruktur wisata yaitu akses, sarana dan prasarana. Dilain 
hal, kesiapan masyarakat juga dibutuhkan untuk menjadi masyarakat yang ramah lingkungan dan sadar wisata. (Mubarak et al., 2019).

\section{Gambar 1. Kondisi Sampah yang Banyak Berserakkan di Sepanjang Jalur Pedestrian Pantai Air Manis}

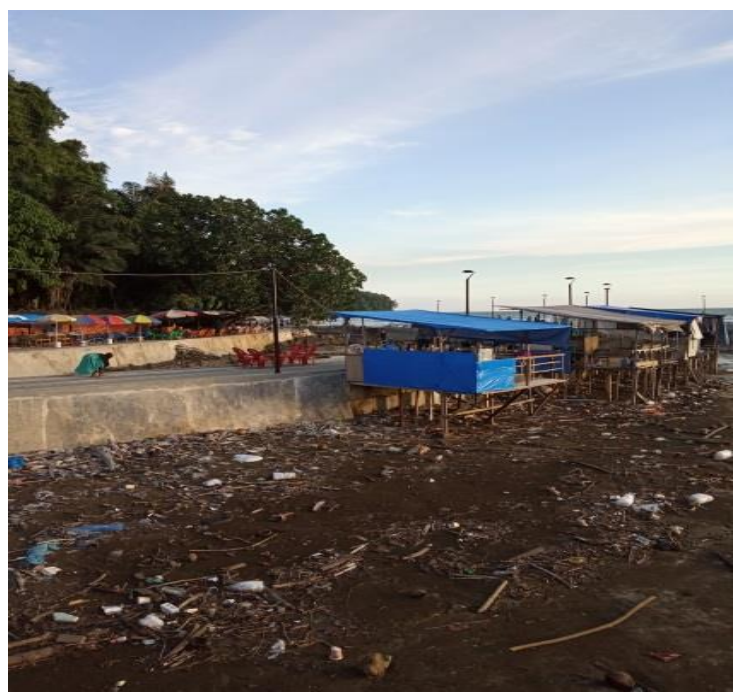

Sumber : Dokumentasi Penelitian 6 Agustus 2020

Kemudian masalah kebersihan kawasan wisata pantai air manis ini yang selalu menjadi keluhan bagi pengunjung yang berkunjung. Dan tentunya yang perlu diperhatikan bahwa jumlah kunjungan wisatawan di tahun 2019 menurun dibanding tahun 2018, oleh sebab itu dilakukannya revitalisasi kawasan wisata pantai air manis, salah satunya dengan membangun jalur pedestrian di pantai air manis yang diharapkan dapat meningkatkan kunjungan wisata pantai air manis. Dari uraian tersebut perlunya dilihat bagaimana dampak pembangunan pedestrian di pantai air manis kota padang terhadap peningkatan jumlah kunjungan objek wisata pantai batu malin kundang.

\section{TINJAUAN PUSTAKA}

\section{Konsep Dampak}

Definisi Dampak berdasarkan pendapat dari (Hosio, 2007), yaitu adanya perubahan yang terlihat pada perilaku atau sikap yang diperoleh dari output kebijakan. menurut definisi diatas maka dapat dikatakan dampak itu suatu perubahan yang terlihat akibat dari output kebijakan terhadap perilaku dan sikap.

Kemudian (S.S, 1996) secara jelas menyampaikan bahwa dampak dari suatu aktivitas pembangunan itu berhubungan langsung dengan dampak utama dan dampak lanjutan atau dampak primer dan dampak sekunder. Adapun dampak yang bersifat utama ini berhubungan perubahan yang diakibatkan secara langsung oleh suatu aktivita pembangunan contohnya yaitu perubahan lingkungan. Sedangkan dampak yang bersifat lanjutan yaitu kelanjutan dari dampak yang telah terjadi sebelumnya atau lanjutan dari dampak utamanya.

Oleh sebab itu, dapat disimpulkan bahwa dampak lanjutan adalah dampak tidak langsung dari adanya dampak yang bersifat utama. Kemudian dilihat dari perkembangan dampak pembangunan ini akan melnciptakan dampak positif yang berupa keuntungan atau dampak negatif yang berupa bentuk yang menciptakan kerugian bagi makhluk hidup terutama manusia itu sendiri.

Selanjutnya inilah dampak-dampak akibat dari aktivitas pengembangan kawasan objek wisata:

1. Dampak Lingkungan

Menurut Mill (Dalam landasan teori kepariwisataan, 2009) dampak nya sebagai berikut:

Dampak Positif :

a. Menarik datangnya para wisatawan dengan terciptanya dan terpeliharanya kebersihan kawasan wisata.

b. Terpeliharanya lingkungan dengan keistimewaannya, contohnya hutan, pantai dan pemandangan yang indah.

Dampak Negatif :

a. Menjadikan Lingkungan rusak dengan adanya polusi atau pencemaran contohnya seperti polusi air, udara dan kemacetan jalan. 
b. Rusaknya ekosistem pantai akibat pembuangan sampah sembarangan.

2. Dampak Ekonomi

Dalam bidang ekonomi Mill menjelaskan ada beberapa poin akibat dari suatu pengembangan tempat wisata yaitu dibawah ini:

\section{Dampak Positif}

a. Menciptakan pendapatan baru dengan terbukanya pekerjaan pengembangan daerah wisata.

b. Taraf hidup dan perekonomian masyarakat meningkat.

c. Membuat nilai tukar mata uang rupiah terhadap mata uang asing menigkat.

d. Menolong tanggungjawab beban pembangunan sarana dan prasarana daerah tersebut.

e. keahlian dalam manajerial dan keterampilan masyarakat meningkat yang memacu aktivitas ekonomi lainnya.

Dampak Negatif :

a. anggaran biaya pembangunan sarana dan prasarana menigkat.

b. harga pasar barang-barang lokal dan bahan-bahan pokok meningkat.

c. berjalanya uang ke luar negeri karena konsumen menuntut barang-barang impor untuk bahan konsumsi tertentu.

Dengan begitu setelah penyampaian dari para ahli diatas maka dapat ditarik kesimpulan bahwa dampak itu berubahnya suatu objek ataupun daerah khusunya tempat wisata dari yang sbelumnya yang tindakan tersebut diambil oleh kebijakan pemerintah dengan melahirkan dampak positif dan negatif atau dampak lingkungan atau dampak ekonomi.

\section{Konsep Pembangunan}

Todaro (2000:92) dalam ngusmanto (2015) menjelaskan bahwa aktivitas pembangunan haruslah dimengerti sebagai proses yang kompleks dan multidimensional, dengan kerjasama melalui aktivitas pengorganisasianpengorganisasian, peninjauan kembali atas sistem-sistem ekonomi dan sosial secara menyeluruh lalu maningkatnya output pendapatan, berubahnya sutu yang dasar seperti stuktur-struktur kelembagaan, sosial dan administrasi, tingkah laku masyarakat dan bahkan masuk kepada adat istiadat, kebiasaan dan sistem keyakinan yang ada dalam masyarakat itu sendiri.

Jadi dapat disimpulkan bahwa pembangunan adalah proses kegiatan yang kompleks dengan berbagai perubahan terhadap struktur sosial , sikap-sikap masyarakat dan institusi-institusi nasional namun selalu mengedepankan kekhasan masyarakat dalam hal sejarah, ekologi, kebudayaan dan sebagainya serta bertujuan untuk kemakmuran masyarakat dan berdampak baik terhadap masyarakat.

\section{Konsep Pedestrian}

Kata Pedestarians bermula dari istilah bahasa yunanni, yaitu pedos dengan arti kaki, sehingga pedestarians dapat dimaksud sebagai pejalan kaki atau orang berjalan kaki, kemudian jalan merupakan bangunan diatas bumi yang memperlancar aktivitas manusia dalam tujuannya berjalan. Pedestrians ini juga diartikan kegiatan manusia yang berpindah dari tempat awal berpijak ke tempat yang lainnya.

Berdasarkan pendapat (Iswanto, 2006), setiap bagian jalan perlu dilengkapi dengan adanya pembangunan jalur pedestrians apabila disetiap jalan tersebut adanya kawasan yang berpoteni dapat menciptakan aktivitas berjalan kaki. tetapi jalur pedestrianss dalam hal di tempat perkotaan biasanya ditujukan sebagai ruang khusus untuk pejalan kaki yang bertujuan untuk sarana pergerakkan yang dapat memberikan kesam aman dan nyaman bagi pejalan kaki dari kemungkinan bahaya datang seperti aktivitas padat kendaraan bermotor. Di Indonesia pedestrians ini lebih dikenal 
Fernando, Adil Mubarak। Dampak Pembangunan Pedestrian di Pantai Air Manis Kota Padang dalam Rangka Kunjungan Wisatawan Ke Objek Wisata Pantai Batu Malin Kundang

dengan istilah trotoar oleh masyaakat dengan ukuran selebar $1,5 \mathrm{~m}$ sampai $2 \mathrm{~m}$ atau lebih memanjang sepanjang jalan.

\section{Konsep Pengelolaan Objek Wisata}

Menurut (Maisardi, 2005) memaparkan bahwa pengelolaan suatu kawasan wisata adalah aktivitas atau kebijakan yang diambil oleh pemerintah bekerja sama dengan organsiasi swasta atau masyarakat itu sendiri dengan tujuan membuat kawasan wisata tersebut menjadi nyaman dan menyenangkan untuk wisatawan berkunjung. Salah satu contoh pengelolaan yang dapat dilaksanakan yaitu dengan cara mempersiapkan sarana dan prasarana yang mendukung tetapi tidak merubah kekhasan dari tempat wisata tersebut. Dan pembangunan ini dapat dilakukan oleh pemerintah bersama-sama dengan swasta maupun masyarakat tetapi harus memperhatikan aspek-aspek yang berpotensi menimbulkan dampak buruk seperti aspek lingkungan, struktur budaya masyarakat, keamanan, akses dan lain sebagainya.

Jadi berdasarkan pemaparan dari ahli diatas bahwa yang dimaksud dengan pengelolaan kawasam wisata dalam penelitian ini adalah aktivitas yang dilaksanakan oleh pihak pemerintah bersama-sama dengan swasta maupun masyarakat melakukan pembenahan dengan melaksanakan pembangunan sarana pendukung objek wisata yang memperhatikan aspek lingkungan dan budaya masyarakat setempat.

\section{METODE PENELITIAN}

Penelitian ini kualitatif dengan analisis deskriptif. Lokasi yang diambil yaitu di pantai air manis kota padang. Informan di tentukan dengan cara purposive sampling yaitu mendapati narasumber yang sesuai dengan kebutuhan dan tujuan penelitian. Adapun informan dalam penelitian ini yaitu pengunjung dan pedagang di objek wisata pantai air manis, pegawai kelurahan air manis, lalu PPK PBL Kemen PUPR serta Kasi usaha industri wisata Disparbud
Kota Padang. Pengumpulan data dilaksanakan dengan cara wawancara dan studi dokumentasi. Teknik triangulasi digunakan untuk menguji keabsahan data penelitian.

\section{HASIL DAN PEMBAHASAN \\ Pembangunan Pedestrian di Pantai Air Manis Kota Padang}

Menurut (Maisardi, 2005) memaparkan bahwa pengelolaan suatu kawasan wisata adalah aktivitas atau kebijakan yang diambil oleh pemerintah bekerja sama dengan organsiasi swasta atau masyarakat itu sendiri dengan tujuan membuat kawasan wisata tersebut menjadi nyaman dan menyenangkan untuk wisatawan berkunjung. Salah satu contoh pengelolaan yang dapat dilaksanakan yaitu dengan cara mempersiapkan sarana dan prasarana yang mendukung tetapi tidak merubah kekhasan dari tempat wisata tersebut. Dan pembangunan ini dapat dilakukan oleh pemerintah bersama-sama dengan swasta maupun masyarakat tetapi harus memperhatikan aspek-aspek yang berpotensi menimbulkan dampak buruk seperti aspek lingkungan, struktur budaya masyarakat, keamanan, akses dan lain sebagainya.

Seperti yang terlihat di lapangan Pembangunan pedestrian ini merupakan program revitalisasi kawasan pantai batu malin kundang yang membangun sarana dan prasarana salah satunya pedestrian ini. Digagas oleh pemerintah Kota Padang yang bekerja sama dengan Kemen PUPR menghasilkan jalur pedestrian dari pulau pisang ketek sampai ke batu malin kundang. Pembangunan pedestrian ini bertujuan untuk meningkatkan kualitas dari kawasan tersebut dengan memperhatikan kenyamanan bagi pengunjung karena telah ada taman dan tempat peristirahatannya. Namun ada beberapa permasalahan yaitu adanya beberapa pedagang yang berdagang dengan memakan jalur pejalan kaki yang membuat pengunjung sedikit terganggu dengan hal itu lalu permasalahan 
Fernando, Adil Mubarak। Dampak Pembangunan Pedestrian di Pantai Air Manis Kota Padang dalam Rangka Kunjungan Wisatawan Ke Objek Wisata Pantai Batu Malin Kundang

kebersihan juga masih menjadi kendala karena masih banyak sampah yang berserakkan di Pantai Air Manis membuat kurang bagusnya pemandangan pantai.

\section{Dampak Lingkungan Pembangunan Pedestrian Pantai Air Manis Kota Padang}

Menurut Mill (Dalam landasan teori kepariwisataan, 2009) dampak lingkungan dari pengembangan kawasan wisata adalah:

Dampak Positif :

1. Menarik datangnya para wisatawan dengan terciptanya dan terpeliharanya kebersihan kawasan wisata.

2. Terpeliharanya lingkungan dengan keistimewaannya, contohnya hutan, pantai dan pemandangan yang indah.

Dampak Negatif :

1. Menjadikan Lingkungan rusak dengan adanya polusi atau pencemaran contohnya seperti polusi air, udara dan kemacetan jalan.

2. Rusaknya ekosistem pantai akibat pembuangan sampah sembarangan.

Seperti yang terlihat di lapangan bahwa Pembangunan jalur Pedestrian di Pantai Air Manis merupakan bagian dari program pemerintah kota padang yaitu melakukan revitalisasi kawasan wisata air manis dan pembangunan ini harus memperhatikan aspek lingkungan dan dampak yang akan ditimbulkan oleh karena itu dampak lingkungan yang timbul setelah adanya pembangunan jalur pedestrian tersebut adalah kawasan wisata pantai air manis menjadi lebih tertata rapi dan membuat kondisi sapta pesona objek wisata pantai air manis menjadi lebih baik dengan meningkatnya aspek keindahan dan kesejukkan alam pantai air manis tersebut. Tetapi ada beberapa dampak negatif yang ditimbulkan seperti kurang terpeliharanya kebersihan dengan sampah masih banyak berserakkan lalu adanya air tergenang di dekat batu malin kundang yang menciptakan polusi air serta bangunan pedestrian tersebut banyak yang sudah rusak dan berlubang untuk itu diperlukan perhatian dalam hal pemeliharaannya.

\section{Dampak Ekonomi Pembangunan Pedestrian di Pantai Air Manis Kota Padang \\ Dalam bidang ekonomi Mill} menjelaskan ada beberapa poin akibat dari suatu pengembangan tempat wisata yaitu dibawah ini:

Dampak Positif:

1. Menciptakan pendapatan baru dengan terbukanya pekerjaan pengembangan daerah wisata.

2. Taraf hidup dan perekonomian masyarakat meningkat.

3. Membuat nilai tukar mata uang rupiah terhadap mata uang asing menigkat.

4. Menolong tanggungjawab beban pembangunan sarana dan prasarana daerah tersebut.

5. Keahlian dalam manajerial dan keterampilan masyarakat meningkat yang memacu aktivitas ekonomi lainnya.

Dampak Negatif :

1. Anggaran biaya pembangunan sarana dan prasarana menigkat.

2. Harga pasar barang-barang lokal dan bahan-bahan pokok meningkat.

3. Berjalanya uang ke luar negeri karena konsumen menuntut barangbarang impor untuk bahan konsumsi tertentu.

Seperti yang terlihat di lapangan bahwa dampak ekonomi dari pembangunan jalur Pedestrian di Pantai Air Manis ini adalah meningkatkan pendapatan pedagang yang berjualan di kawasan pantai air manis, dan dapat meningkatkan perekonomian masyarakat air manis itu sendiri, karena setelah adanya pembangunan jalur pedestrian ini membuat masyarakat air manis banyak yang memulai berjualan di pinggir jalan tersebut. walaupun dengan adanya pembangunan ini tentu membuat biaya pembangunan meningkat juga. 
Fernando, Adil Mubarak। Dampak Pembangunan Pedestrian di Pantai Air Manis Kota Padang dalam Rangka Kunjungan Wisatawan Ke Objek Wisata Pantai Batu Malin Kundang

Dampak Pembangunan Pedestrian di Pantai Air Manis Kota Padang dalam Rangka Kunjungan Wisatawan Ke Objek Wisata Pantai Batu Malin Kundang

Daya tarik utama kawasan wisata pantai air manis adalah batu malin kundangnya yang terkenal secara nasional dengan cerita legenda anak durhaka yang dikutuk menjadi batu. Banyak wisatawan yang berlomba-lomba melihat dan mengabadikan momen bersama batu malin kundang tersebut. Untuk itu setelah adanya pembangunan pedestrian yang menghubungkan langsung pengunjung dengan batu malin kundang ini seharusnya membuat wisatawan semakin banyak berkunjung ke pantai air manis karena setelah adanya pedestrian ini membuat akses menuju batu malin kundang menjadi lebih mudah. Tetapi berbeda hasilnya setelah melihat fenoena di lapangan bahwa bukan terjadi peningkatan malahan terjadi penurunan kunjungan wisatawan Seperti pada tabel kunjungan wisata pantai air manis berikut ini.

Tabel 2. Jumlah Kunjungan Wisata

Pantai Air Manis Rata-Rata Perbulan dalam Kurun Waktu Dua Tahun Terakhir

\begin{tabular}{|c|c|}
\hline $\begin{array}{l}\text { Rata-rata per } \\
\text { bulan jumlah } \\
\text { kunjungan } \\
\text { wisata tahun } \\
2018 \text { dan } 2019\end{array}$ & $\begin{array}{c}\text { Jumlah kunjungan } \\
\text { wisata pantai air } \\
\text { manis bulan } \\
\text { januari-februari } \\
2020\end{array}$ \\
\hline $2018 \quad 2019$ & Januari Februari \\
\hline $34.760 \quad 19.410$ & 26.840 \\
\hline $\begin{array}{l}\text { Sumber : Dina } \\
\text { Kebudayaan Kota Pc }\end{array}$ & $\begin{array}{l}\text { Is Pariwisata } \\
\text { adang } 2019\end{array}$ \\
\hline $\begin{array}{l}\text { Jumlah kunjunga } \\
\text { malin kundang pada } \\
\text { terjadi penurunan da } \\
\text { jumlah kunjungan pa } \\
\text { kembali menurun }\end{array}$ & $\begin{array}{l}\text { an wisata pantai batı } \\
\text { a tahun } 2018 \text { ke } 2019 \\
\text { an terjadi peningkatar } \\
\text { ada januari } 2020 \text { tetap } \\
\text { bulan februari lalu }\end{array}$ \\
\hline
\end{tabular}

ditutup pada bulan maret. Ini disebabkan karena adanya pandemi virus covid-19 yang menyebar ke dunia dan indonesia salah satunya, oleh karena itu segala kegiatan pariwisata terhenti untuk beberapa saat dan tentu imbasnya kepada penurunan kunjungan wisata dibulan februari. Setelah adanya pembangunan pedestrian di pantai air manis ini menimbulkan dampak lingkungan dan dampak ekonomi, dari uraian di atas jadi dapat disimpulkan bahwa pembangunan jalur pedestrrian di pantai air manis kota padang ini membuat menurunnya jumlah kunjungan ke objek wisata pantai batu malin kundang.

\section{PENUTUP}

Dari hasil penelitian di lapangan maka dapat ditarik beberapa poin penting yaitu :

1. Pembangunan pedestrian di pantai air manis kota padang merupakan bagian dari program revitalisasi kawasan pantai batu malin kundang yang digagas oleh pemerintah Kota Padang yang bekerja sama dengan Kemen PUPR menghasilkan jalur pedestrian dari pulau pisang ketek sampai ke batu malin kundang. Pembangunan pedestrian ini bertujuan untuk meningkatkan kualitas dari kawasan tersebut dengan memperhatikan kenyamanan bagi pengunjung karena telah ada taman dan tempat peristirahatannya. Namun ada beberapa permasalahan yaitu adanya beberapa pedagang yang berdagang dengan memakan jalur pejalan yang membuat pengunjung sedikit terganggu dengan hal itu lalu permasalahan kebersihan juga masih menjadi kendala karena masih banyak sampah yang berserakkan di Pantai Air Manis membuat kurang bagusnya pemandangan pantai.

2. Dampak lingkungan yang timbul setelah adanya pembangunan jalur pedestrian tersebut adalah kawasan wisata pantai air manis menjadi lebih tertata rapi dan membuat kondisi sapta 
pesona objek wisata pantai air manis menjadi lebih baik dengan meningkatnya aspek keindahan dan kesejukkan alam pantai air manis tersebut. Tetapi ada beberapa dampak negatif yang ditimbulkan seperti kurang terpeliharanya kebersihan dengan sampah masih banyak berserakkan lalu adanya air tergenang di dekat batu malin kundang yang menciptakan polusi air serta bangunan pedestrian tersebut banyak yang sudah rusak dan berlubang untuk itu diperlukan perhatian dalam hal pemeliharaannya.

3. Dampak ekonomi yang timbul dari pembangunan jalur Pedestrian di Pantai Air Manis ini adalah meningkatkan pendapatan pedagang yang berjualan di kawasan pantai air manis, dan dapat meningkatkan perekonomian masyarakat air manis itu sendiri, karena setelah adanya pembangunan jalur pedestrian ini membuat masyarakat air manis banyak yang memulai berjualan di pinggir jalan tersebut. walaupun dengan adanya pembangunan ini tentu membuat biaya pembangunan meningkat juga.

\section{DAFTAR KEPUSTAKAAN}

Bahar, M. (2000). Pengantar Ilmu Pariwisata. PT Pradnya Paramita.

Bakaruddin. (1990). Geografi Pariwisata dan Permasalahannya. IKIP.

Hosio, J. E. (2007). Cetakan Kedua. Kebijakan Publik Dan Desentralisasi: Esai- Esai Dari Sorong.

Iswanto, D. (2006). Pengaruh Elemen Elemen Pelengkap Jalur Pedestrian Terhadap Kenyamanan Pejalan Kaki Studi Kasus Penggal Jalan Pandanaran Dimulai dari Jalan Randusari Hingga Kawasan Tugu Muda. Enclosure, 5(1), 21-29.
Maisardi. (2005). Eksistensi Kawasan Pantai Air Manis Sebagai Objek Wisata Kota Padang. FIS UNP.

Mubarak, A., Syamsir, S., \& Frinaldi, A. (2019). Workshop pengelolaan lahan bekas tambang bagi aparatur pemerintah Nagari Sikabau dan Nagari Tebing Tinggi Kecamatan Pulau Punjung Kabupaten Dharmasraya. Unri Conference Series: Community Engagement, 1, 113-120. https://doi.org/10.31258/unricsce.1.11 3-120

Ngusmanto, H., \& Si, M. Pemikiran Dan Praktik Administrasi Pembangunan.

S.S, Y. (1996). Perubahan Lingkungan Tantangan Bagi Manusia. In Gadjah Mada Press. Gadjah Mada Press.

Undang-Undang Nomor 10 Tahun 2009 Tentang Kepariwisataan. 